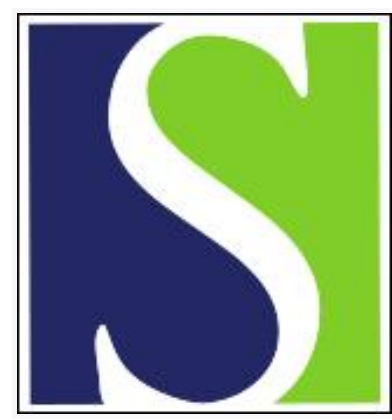

Scand J Work Environ Health 1993;19(2):73-84

https://doi.org/10.5271/sjweh.1494

Issue date: 01 Apr 1993

A conceptual model for work-related neck and upper-limb musculoskeletal disorders.

by Armstrong TJ, Buckle P, Fine LJ, Hagberg M, Jonsson B, Kilbom A, Kuorinka IA, Silverstein BA, Sjogaard G, Viikari-Juntura ER

Affiliation: Center for Ergonomics, University of Michigan, Ann Arbor 48109-2117.

The following articles refer to this text: 2010;36(1):3-24;

2015;41(2):140-152; 2017;43(6):526-539; 2020;46(3):248-258

This article in PubMed: www.ncbi.nlm.nih.gov/pubmed/8316782 


\title{
A conceptual model for work-related neck and upper-limb musculoskeletal disorders
}

\author{
by Thomas J Armstrong, PhD, ${ }^{1}$ Peter Buckle, PhD, ${ }^{2}$ Lawrence J Fine, MD, ${ }^{3}$ Mats Hagberg, MD, ${ }^{4}$ \\ Bengt Jonsson, MD, ${ }^{4}$ Asa Kilbom, MD, ${ }^{4}$ Ilkka AA Kuorinka, DrMedSc, ${ }^{5}$ Barbara A Silverstein, \\ $\mathrm{PhD},{ }^{6}$ Gisela Sjogaard, DrMedSc, ${ }^{7}$ Eira RA Viikari-Juntura, DrMedSc ${ }^{5}$
}

\begin{abstract}
ARMSTRONG TJ, BUCKLE P, FINE LJ, HAGBERG M, JONSSON B, KILBOM A, KUORINKA IAA, SILVERSTEIN BA, SJOGAARD G, VIIKARI-JUNTURA ERA. A conceptual model for workrelated neck and upper-limb musculoskeletal disorders Scand J Work Environ Health 1993;19:7384. This paper presents a conceptual model for the pathogenesis of work-related musculoskeletal disorders. The model contains sets of cascading exposure, dose, capacity, and response variables, such that response at one level can act as dose at the next. Response to one or more doses can diminish or increase the capacity for responding to successive doses. The model is used as a framework for discussing the development of work-related muscle, tendon, and nerve disorders. It is intended as a beginning, to be modified to explain new findings as they become available. In research, it can help to identify areas needing additional data for the development and expression of work-related musculoskeletal disorders. Researchers can use it to design laboratory and field studies. In practice, it demonstrates the relationship between common exposure factors and different responses. This information can be used to evaluate and design jobs for the prevention of work-related musculoskeletal disorders.
\end{abstract}

Key terms: carpal tunnel syndrome, cumulative trauma disorders, dose-response, fatigue, nerve pathogenesis, repetitive strain injuries, tendinitis, tendon and muscle disorder, work-related disorders.

This paper concerns a model for the development of work-related neck and upper-limb disorders. It brings together the collective experience of researchers, from many countries, who have each recognized the need for a model that addresses both scientific and practical aspects and their interactions.

The scientific literature shows that the health problems considered in the model are found worldwide, in both industrial and nonindustrial groups. Historical records and other documentation show that many of the disorders in question have been recognized for centuries, and their association with occupations was recorded long before sickness benefit schemes and

1 Center for Ergonomics, University of Michigan, Ann Arbor, Michigan, United States.

2 The Robens Institute of Industrial and Environmental Health and Safety, University of Surrey, Surrey, England.

3 National Institute for Occupational Safety and Health Cincinnati, Ohio, United States.

4 National Institute of Occupational Health, Solna, Sweden.

5 Institute of Occupational Health, Helsinki, Finland.

6 Safety and Health Assessment and Research Program (SHARP), Washington State Department of Labor and Industries, Olympia, Washington, United States.

7 National Institute of Occupational Health, Copenhagen, Denmark.

Reprint requests to: Dr TJ Armstrong, Center for Ergonomics, University of Michigan, 1205 Beal-IOE Building, Ann Arbor, MI 48109-2117, USA. compensation claims were in existence. It is perhaps inevitable that any study or discussion of the expression of the disorders quickly leads to a consideration of the preexisting social conditions, and the effects on individuals and organizations. The balance between such factors is complex and is further justification for developing a model such as the one presented in this communication.

Regardless of national and cultural differences in social thoughts or attitudes towards states of health, musculoskeletal problems are found. The extent of the problems is difficult to establish because definitions, diagnostic criteria, and official statistics are rarely comparable from country to country.

Limitations in establishing causality are evident in current methodologies when these methodologies are applied to most workplace studies. These limitations should not be seen as a barrier to the interpretation of data from the many epidemiologic studies that identify associations, but rather as limitations that exist in many areas of health-related research. A model of the interaction between physiological, mechanical, individual, and psychosocial factors provides a framework for integrating epidemiologic findings with laboratory studies.

This model was developed to highlight the multifactorial nature of work-related neck and upper-limb disorders and to assist in the understanding of the complex nature of the interactions between exposure, dose, capacity, and response. The model can also be considered a tool for research planning and study interpretation. 
There is an important role for researchers in providing those responsible for prevention and rehabilitation with the information required to develop effective strategies. The model outlined reflects this need. It is hoped and expected that the model will be developed further.

\section{Work relatedness}

Musculoskeletal disorders should be characterized as "work-related diseases" rather than as "occupational diseases" (1). An occupational disease is defined as a disease for which there is a direct cause-effect relationship between hazard and disease (eg, asbestos-asbestosis). Work-related diseases are defined as multifactorial when the work environment and the performance of work contribute significantly, but as one of a number of factors, to the causation of disease (1). Work-related diseases can be partially caused by adverse work conditions. They can be ex- acerbated by workplace exposures, and they can impair work capacity. It is important to remember that personal characteristics and environmental and sociocultural factors usually play a role as risk factors for these diseases. Some of the health problems presented in the model have characteristics of both work-related and occupational diseases, especially if exposure levels are high.

The "work relatedness" of musculoskeletal disorders is supported by numerous epidemiologic studies (2-21). (See table 1.) It can be seen that these disorders are not unique to any one occupational group. Reported occupations include meat processors, letter carriers, office workers, and manufacturers of many products. The common trait of these groups is repetitive or intensive use of the hands.

The incidence and prevalence of musculoskeletal disorders in reference populations with reduced hand work are low, but not zero. (See table 1.) This morbidity is evidence of other, probably nonwork-related

Table 1. Epidemiologic studies of the relationship between work exposure and musculoskeletal response variables provide evidence of a dose-response relationship. (95\% Cl=95\% confidence interval, EMG = electromyography)

\begin{tabular}{|c|c|c|c|c|c|c|c|c|}
\hline Study population & Exposure & $\begin{array}{l}\text { Study } \\
\text { design }\end{array}$ & $\begin{array}{l}\text { Exposed } \\
\text { prevalence } \\
\text { or } \\
\text { incidence }\end{array}$ & $\begin{array}{l}\text { Referents' } \\
\text { prevalence } \\
\text { or } \\
\text { incidence }\end{array}$ & Risk & $95 \% \mathrm{Cl}$ & $\begin{array}{l}\text { Refer- } \\
\text { ence } \\
\text { num- } \\
\text { ber }\end{array}$ & Response and comment \\
\hline $\begin{array}{l}\text { Male industrial workers be- } \\
\text { longing to an occupational } \\
\text { health center: } 20 \text { cases of } \\
\text { degenerative shoulder ten- } \\
\text { dinitis ( } 3 \text { cases of tendinitis } \\
\text { due to general inflamma- } \\
\text { tory disorder excluded), } \\
\text { contrasted to } 34 \text { referents } \\
\text { matched for age and work- } \\
\text { shop ( } 2 \text { referents for each } \\
\text { case) }\end{array}$ & $\begin{array}{l}\text { Work with hands at or } \\
\text { above shoulder level; ex- } \\
\text { posure assessed by inter- } \\
\text { view and observation of } \\
\text { physician }\end{array}$ & $\begin{array}{l}\text { Case- } \\
\text { referent }\end{array}$ & $\begin{array}{l}11 \text { exposed } \\
\text { cases }\end{array}$ & $\begin{array}{l}5 \text { exposed } \\
\text { referents }\end{array}$ & 11 & $2.7-42$ & 2 & $\begin{array}{l}\text { Shoulder tendinitis; adjust- } \\
\text { ment for potential con- } \\
\text { founders (age) not per- } \\
\text { formed in the analysis }\end{array}$ \\
\hline $\begin{array}{l}\text { Shipyard welders ( } 131 \text { males) } \\
\text { with more than five years } \\
\text { of welding experience, con- } \\
\text { trasted to office workers ( } 57 \\
\text { males) age } 40 \text { years or older }\end{array}$ & $\begin{array}{l}\text { Localized shoulder muscle } \\
\text { fatigue; work with elevated } \\
\text { arms with hands at or above } \\
\text { shoulder level; exposure } \\
\text { measured for welders by } \\
\text { observation and EMG in an- } \\
\text { other study }\end{array}$ & $\begin{array}{l}\text { Cross- } \\
\text { sectional }\end{array}$ & $18 \%$ & $2 \%$ & 13 & $1.7-95$ & 3 & $\begin{array}{l}\text { Shoulder tendinitis; adjust- } \\
\text { ment for potential con- } \\
\text { founders (age) not per- } \\
\text { formed in the analysis; the } \\
\text { number of welding years } \\
\text { not associated with out- } \\
\text { come }\end{array}$ \\
\hline $\begin{array}{l}\text { Meat cutters ( } 90 \text { males) } \\
\text { contrasted to construction } \\
\text { foremen ( } 77 \text { males) }\end{array}$ & $\begin{array}{l}\text { "Overstrain of the exten- } \\
\text { sors and flexors of the wrist } \\
\text { and fingers"; exposure data } \\
\text { from previous published } \\
\text { literature and plant walk } \\
\text { throughs }\end{array}$ & $\begin{array}{l}\text { Cross- } \\
\text { sectional }\end{array}$ & $8.9 \%$ & $1.3 \%$ & 7.4 & $0.91-61$ & 4 & $\begin{array}{l}\text { Tennis elbow (lateral epi- } \\
\text { condylitis) }\end{array}$ \\
\hline $\begin{array}{l}\text { Packers ( } 118 \text { females) con- } \\
\text { trasted to employees in } \\
\text { nonstrenuous jobs (197 fe- } \\
\text { male office workers and } \\
\text { supervisors) }\end{array}$ & $\begin{array}{l}\text { Work tasks strenuous to } \\
\text { the muscle-tendon struc- } \\
\text { tures of the upper limb; ex- } \\
\text { posure data from previous } \\
\text { published literature and } \\
\text { plant walk throughs }\end{array}$ & Cohort & $7.0 \%$ & $1.1 \%$ & 6.4 & $\cdots$ & 5 & $\begin{array}{l}\text { Epicondylitis (lateral and } \\
\text { medial) causing a visit to } \\
\text { the doctor; adjustment for } \\
\text { potential confounders (age) } \\
\text { not performed in the analy- } \\
\text { sis }\end{array}$ \\
\hline $\begin{array}{l}\text { Meat processing workers } \\
\text { ( } 377 \text { meatcutters, sausage } \\
\text { makers, packers) con- } \\
\text { trasted to workers in non- } \\
\text { strenuous jobs ( } 332 \text { office } \\
\text { workers, maintenance men, } \\
\text { supervisors) }\end{array}$ & $\begin{array}{l}\text { Work tasks strenuous to } \\
\text { the muscle tendon struc- } \\
\text { tures of the upper limb; ex- } \\
\text { posure data from plant walk } \\
\text { throughs }\end{array}$ & $\begin{array}{l}\text { Cross- } \\
\text { sectional }\end{array}$ & $0.8 \%$ & $0.8 \%$ & 1 & . & 6 & $\begin{array}{l}\text { Epicondylitis (lateral and } \\
\text { medial) }\end{array}$ \\
\hline $\begin{array}{l}\text { Scissors makers ( } 90 \text { fe- } \\
\text { males, } 3 \text { males) contrasted } \\
\text { to shop assistants (females) } \\
\text { in a big department store }\end{array}$ & $\begin{array}{l}\text { Number of pieces handled; } \\
\text { grasping with the fingers } \\
\text { wide open }\end{array}$ & $\begin{array}{l}\text { Cross- } \\
\text { sectional }\end{array}$ & $18 \%$ & $14 \%$ & 1.4 & $0.7-2.9$ & 7 & $\begin{array}{l}\text { Hand-wrist tendinitis (De- } \\
\text { Quervain); tendinitis related } \\
\text { to number of pieces han- } \\
\text { dled }\end{array}$ \\
\hline $\begin{array}{l}\text { Assembly-line packers ( } 152 \\
\text { females) in food production } \\
\text { industry contrasted to shop } \\
\text { assistants ( } 133 \text { females) in } \\
\text { a department store (cashi- } \\
\text { ers excluded) }\end{array}$ & $\begin{array}{l}\text { Repetitive arm work, repeti- } \\
\text { tive motions up to } 25000 \\
\text { cycles per workday; ex- } \\
\text { posure assessed from ob- } \\
\text { servation analysis of video } \\
\text { and from an interview }\end{array}$ & $\begin{array}{l}\text { Cross- } \\
\text { sectional }\end{array}$ & $56 \%$ & $14 \%$ & 8.1 & $4.5-14.6$ & 8 & $\begin{array}{l}\text { Muscle-tendon syndrome; } \\
\text { adjustment for potential } \\
\text { confounders (age) not per- } \\
\text { formed in the analysis }\end{array}$ \\
\hline
\end{tabular}


Table 1. Continued.

\begin{tabular}{|c|c|c|c|c|c|c|c|c|}
\hline Study population & Exposure & $\begin{array}{l}\text { Study } \\
\text { design }\end{array}$ & $\begin{array}{l}\text { Exposed } \\
\text { prevalence } \\
\text { or } \\
\text { incidence }\end{array}$ & $\begin{array}{l}\text { Referents' } \\
\text { prevalence } \\
\text { or } \\
\text { incidence }\end{array}$ & Risk & $95 \% \mathrm{Cl}$ & $\begin{array}{l}\text { Refer- } \\
\text { ence } \\
\text { num- } \\
\text { ber }\end{array}$ & Response and comment \\
\hline Industrial workers $(\mathrm{N}=652)$ & $\begin{array}{l}\text { High-force high-repetitive } \\
\text { jobs compared with low- } \\
\text { force low-repetitive jobs; } \\
\text { EMG and video analysis of } \\
\text { jobs }\end{array}$ & $\begin{array}{l}\text { Cross- } \\
\text { sectional }\end{array}$ & $12 \%$ & $0.6 \%$ & 29.4 & . & 9 & $\begin{array}{l}\text { Hand and wrist tendinitis; } \\
\text { control for age, gender, } \\
\text { plant years on the job }\end{array}$ \\
\hline $\begin{array}{l}\text { Packaging and folding } \\
\text { workers ( } 41 \text { males, } 328 \text { fe- } \\
\text { males) contrasted to knit- } \\
\text { ting workers ( } 203 \text { males, } \\
149 \text { females) }\end{array}$ & $\begin{array}{l}\text { Exposure according to job } \\
\text { categories; no exposure } \\
\text { measurements }\end{array}$ & $\begin{array}{l}\text { Cross- } \\
\text { sectional }\end{array}$ & $3.3 \%$ & $0.9 \%$ & 3.9 & $1.1-14$ & 10 & $\begin{array}{l}\text { Hand-wrist tendinitis (De- } \\
\text { Quervain); adjustment for } \\
\text { potential confounders (gen- } \\
\text { der, age) not performed in } \\
\text { the analysis }\end{array}$ \\
\hline $\begin{array}{l}\text { Sausage makers ( } 107 \text { fe- } \\
\text { males) contrasted to em- } \\
\text { ployees in nonstrenuous } \\
\text { jobs ( } 197 \text { female office } \\
\text { workers and supervisors) }\end{array}$ & $\begin{array}{l}\text { Work tasks strenuous to } \\
\text { the muscle-tendon struc- } \\
\text { tures of the upper limb; ex- } \\
\text { posure data from previous- } \\
\text { ly published literature and } \\
\text { plant walk throughs }\end{array}$ & Cohort & $16.3 \%$ & $0.7 \%$ & 24 & . & 5 & $\begin{array}{l}\text { Tenosynovitis or peritendi- } \\
\text { nitis (including DeQuervain) } \\
\text { causing a visit to the doc- } \\
\text { tor }\end{array}$ \\
\hline
\end{tabular}
(1970 plant walk throughs

Scissors makers (90 females, 3 males) contrasted males) in a big department store

Data entry operators ( $50 \mathrm{fe}$ males, 3 males) contrasted to office workers (55 fe. males and males)

Number of pieces handled

wide open

Cross-
sectional

$61 \%$

$28 \%$

$4.1 \quad 2.3-7.2$

7 Tension neck syndrome; adjustment for potential confounders (gender, age) not performed in the analysis

Constrained head and arm posture

$\begin{aligned} & \text { Cross- } \\ & \text { sectional }\end{aligned}$
$38 \%$$\quad 11 \%$

11 Tension neck syndrome; adjustment for potential confounders (gender, age) not performed in the analysis

\begin{tabular}{|c|c|c|c|c|c|c|c|c|}
\hline $\begin{array}{l}\text { Assembly-line workers in a } \\
\text { shoe manufacturing line } \\
\text { (102 females) contrasted to } \\
\text { nonassembly workers ( } 102 \\
\text { females) (Rhomboid mus- } \\
\text { cle tenderness) }\end{array}$ & $\begin{array}{l}\text { Observations from films of } \\
\text { the work tasks; each as- } \\
\text { sembly-line worker handled } \\
3400 \text { shoes per day; repeti- } \\
\text { tive arm movements }\end{array}$ & $\begin{array}{l}\text { Cross- } \\
\text { sectional }\end{array}$ & $14 \%$ & $1 \%$ & 7.3 & $1.6-33$ & 12 & $\begin{array}{l}\text { Tension neck syndrome, } \\
\text { adjustment for potential } \\
\text { confounders (age) not per- } \\
\text { formed in the analysis }\end{array}$ \\
\hline $\begin{array}{l}\text { Workers for a jet engine } \\
\text { manufacturer ( } 27 \text { females } \\
\text { and } 3 \text { males with carpal tun- } \\
\text { nel syndrome) and } 90 \text { ran- } \\
\text { domly gender-matched }\end{array}$ & Use of vibrating handtools & $\begin{array}{l}\text { Case- } \\
\text { referent }\end{array}$ & . & $\cdots$ & 13.8 & . & 13 & $\begin{array}{l}\text { Carpal tunnel syndrome } \\
\text { identified from workers' } \\
\text { compensation reports and } \\
\text { plant medical personnel }\end{array}$ \\
\hline
\end{tabular}

gender-matched All butchers from two small
slaughterhouses (17 males)
with $3-32$ years of experience

Industrial workers $(\mathrm{N}=652$

Assembly workers ( $N=479$ ) contrasted to administra tive and clerical workers

Frozen food factory work. ers $(N=207)$

Carpal tunnel syndrome re lease patients ( 38 males) contrasted to hospital and community referents $(\mathrm{N}=$ 143)

Washington state workers (in United States) ment vehicle maintenance workshops using hand as hammer (79 males) contrasted to employees from government vehicle maintenance workshops who did not use hand as hammer (48 males)

Platers in a plant producing paper and pulp machinery (89 males) contrasted to of fice workers at the same plant $(\mathrm{N}=61)$

Vibration $>20$ years
Lifting, tearing, and handling of carcasses with left hand versus using tools with right hand; exposure determined by observation

High-force high-repetitive jobs compared with lowforce low-repetitive jobs: EMG and video analysis of jobs

Various occupations

Frozen food factory workers exposed to cold

Cross- $53 \%$

sectional

$24 \%$

Cross.

$5.6 \%$

sectional

$0.6 \%$

16

$1.7-142$

Cross-

sectional

$47 \%$

$2.3 \quad 1.4-3.7$

16

Cross- $\quad 37 \%$

sectional

.

Case-

$\cdots$

$4.8 \quad 1.5-16$

17 cording to nerve conduc-
tion velocity; no symptoms

Carpal tunnel syndrome; Carpal tunnel syndrome; control for age and gender
Industrial codes - oyster Register $\quad 0.2 \%$ and crab industry workers incidence
Habitual hand hammering Cross- $14 \%$

defined as using the hand sectional

to hammer more than once

view

ording to inter-

Exposure assessed by

questionnaire, observation

and vibration level and

duration measurements:

platers exposed to vibration

mainly during grinding but

mainly during grinding but

hammers

\begin{tabular}{|c|c|c|c|c|c|c|}
\hline $\begin{array}{l}\text { Cross- } \\
\text { sectional }\end{array}$ & $37 \%$ & $20 \%$ & 2.8 & $1.3-6.2$ & 21 & $\begin{array}{l}\text { Hypothenar hammer syn- } \\
\text { drome; right ulnar artery; } \\
\text { adjustment for age in the } \\
\text { anałysis }\end{array}$ \\
\hline
\end{tabular}

anatysis
19 Workers' compensation for carpal tunnel syndrome; female : male ratio $1.2: 1$ and mean age 37.4 years 
causes. These background cases are consistent with the concept of the World Health Organization of "work relatedness" (1).

The variation in the responses reported in table 1 is possibly due to differences in the criteria used for case definitions and the methods of examination. Most researchers define cases by clinical examination (symptoms and clinical findings), but some use clinical findings without symptoms and visa versa.

Because musculoskeletal disorders are a problem common to many different occupations and work groups and because they can involve different tissues and body locations, these disorders are often referred to collectively as cumulative trauma disorders, repetitive trauma disorders, repetitive strain injuries, or overuse syndromes. While a literal interpretation of each term suggests subtle differences, as a practical matter they refer to the same diagnostically related group of problems. The term "work-related musculoskeletal disorder" is used in this paper.

While an exact diagnosis is desirable for affected workers, it is not always possible, particularly in the earliest stages of the development of a musculoskeletal disorder. In most cases it is desirable to intervene before explicit patterns of symptoms develop. Therefore it may be desirable to use case criteria that have a high degree of sensitivity at the expense of specificity. In other words, at the earliest stages of development, it may not be important whether a worker's discomfort is due to a biochemical disturbance in the muscle or to a deformation of the tendon because both can respond to a reduction in work intensity.

Many studies have considered factors such as age, gender, weight, chronic diseases, fitness, and congenital differences. Age and gender have been linked to symptoms of carpal tunnel syndrome $(16,22-24)$;

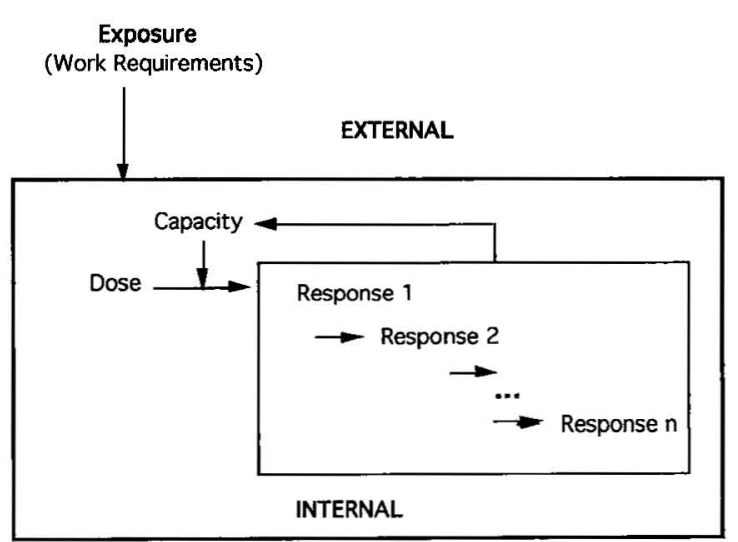

Figure 1. The proposed model contains sets of cascading exposure, dose, capacity, and response variables, such that the response at one level can act as a dose at the next level. In addition, the response to one or more doses can diminish (impairment) or increase (adaptation) the capacity for responding to successive doses. however, the studies with such findings have either been based on nonoccupational populations or the occupational exposure was not quantified. Studies in which occupational exposure was quantified and the level of exposure was high have shown that the risk associated with personal factors was small when compared with that associated with occupational exposures $(9,13,15,25)$. Similar cases have been found for other personal factors of musculoskeletal disorders.

Although musculoskeletal disorders can result in pain and impaired work performance, they can also go unreported. A worker's decision to report a problem can be influenced by his or her personal, social, and economic circumstances. Studies of job satisfaction and stress have, as yet, been inconclusive (2629). Peer pressure can also contribute directly to a worker's decision to report a problem. It can also contribute indirectly to the production of a disorder by encouraging a worker to work faster or slower (30).

Workers' willingness to report musculoskeletal problems may be related to cultural differences which influence their perception and willingness to tolerate pain. Studies of these issues have produced mixed findings $(31,32)$. The progression from disorder to disability is probably strongly influenced by psychosocial, cultural, and economic factors (33).

\section{The model}

The goal of our dose-response model is to account for the factors and processes that result in work-related neck and upper-limb disorders. The ultimate objective of such a model is to specify acceptable limits on work design for a given individual. In its simplest form, a lumped-parameter dose-response model can be characterized as the following four sets of interacting variables: exposure, dose, capacity, and response. (See figure 1.) Because these variables are measures of the system state at any time, they are referred to as state variables.

\section{Exposure}

Exposure refers to the external factors (eg, work requirements) that produce the internal dose (eg, tissue loads and metabolic demands and factors). For example, the geometry of the workplace and the shape of the tools are important determinants of work posture. The size, shape, and weight of work objects are important determinants of tissue loads. Work standards are important determinants of the frequency and velocity of muscle contractions. It also is possible for the response of one tissue to result in a dose that affects another tissue. (See figure 1.) For example, connective tissue can thicken as its adapts to stress, and this thickening can lead to pressure on adjacent nerves and impaired nerve capacity. 
Not all important work requirements and other work environment factors are physical characteristics. Conflicting job demands, such as the need to increase both the quality and quantity of the product, can be important. Even characteristics of the work environment, such as the threat of a plant closing, can also be important, and these characteristics can best be considered as work environment factors rather than as work requirements.

\section{Dose}

Dose refers to those factors that in some way disturb the internal state of the individual. Disturbances may be mechanical, physiological, or psychological. Examples of mechanical disturbances are tissue forces and deformations that are produced as a result of exertion or movement of the body. Examples of physiological disturbances are consumption of metabolic substrates, production of metabolites, ion displacement, and tissue damage. Examples of psychological disturbances are anxiety about the work load and the lack of social support from family.

\section{Response}

Response includes the changes that occur in the state variables of the individual. Examples are a change in substrate, by-product, ion concentrations, temperature, or the shape of tissues. One response can in turn be a new dose, which then produces another response. For example, an exertion of the hand can cause changes in tissue shape and in substrate and metabolite levels, which in turn result in discomfort.

The responses that are produced as a result of another response are referred to as secondary, tertiary, and the like, depending on the number of preceding responses. In the previous example, tissue deformation and substrate and metabolite levels are primary responses, and discomfort is a secondary response.

The relationship between dose and state variable response can be altered by previous exertions. For example, initially an exertion draws on high energy phosphate stores within the muscle. Later, it can draw on the muscle glycogen and fatty acid stores. The effect of a dose can occur immediately or it can require long periods of time. Exertion of force will produce immediate elastic deformation of tendons. Repeated or prolonged exertions over the course of a work shift can result in viscous deformation of tissues. Repeated and prolonged exertions, day after day, can result in changes in the composition of tissue. These changes can result in increased dose tolerance. Such changes are referred to as adaptation and are a desirable effect of training. The changes can also result in reduced capacity, which is an undesirable effect.

A quantitative description of all of the human components and of all of the state variables is not yet possible. Therefore the discussion will focus on examples pertaining to muscles, tendons, and nerves.

\section{Capacity}

Capacity, whether physical or psychological refers to the ability of the individual to resist destabilization due to various doses. Examples include the ability of tissues to resist deformation, the ability to maintain concentrations of metabolites when exposed to forces of exertion or movement or nonphysical factors such as a strong sense of self-esteem or a high capacity to resist mental stress. According to the model capacity can be reduced or enhanced by previous doses and responses. For example, previous exertions can reduce substrate levels or increase metabolite levels so that fewer exertions are tolerated before fatigue and discomfort occur. Similarly, prior exertions can result in residual deformation of connective tissues so that fewer exertions or lower force is required to produce microfailures. Most individuals are able to adapt to certain types and levels of activity. Muscles can develop increased aerobic or anaerobic metabolic capacity. Connective tissues can adapt by becoming stronger; however, not all tissues adapt at the same rate. A muscle can adapt faster than a tendon and result in reduced tendon capacity.

\section{Muscle disorders}

Physical work requirements and individual factors determine muscle force and length characteristics as a function of time, which in turn determines muscle energy requirements. Muscle energy requirements in turn can lead to fatigue, which then can lead to muscle disorders. Muscle responses can be characterized as a series of cascading mechanical and physiological events. Mechanical responses include deformation and the yielding of connective tissues within the muscle, as well as increases in intramuscular tissue pressure, which can affect the muscle blood flow mechanically $(34,35)$. Physiological responses include electrochemical and metabolic changes (36). Initial responses include electrical excitation, shifting ions, activation of contractile proteins, and mechanical deformation of muscle tissues. These responses are followed by shifting concentrations of substrates and metabolites. These local changes are conveyed to the central nervous system by sensory afferent nerves and cause corresponding sensations of effort and discomfort, or what is referred to collectively as "perceived fatigue." Of note is the fact that these sensory afferents simultaneously affect the cardiorespiratory responses to match the increased need for muscle blood flow to supply substrates, including oxygen, and to prevent the accumulation of metabolites. However, if intramuscular pressure is maintained at a high level for prolonged periods of time, as during sustained static contractions, the blood flow can be insufficient, and the changes in intramuscular homeostasis is vital for force development (37). 
Muscular damage can be a result of high tension development, as seen especially in eccentric contractions, which can lead to muscle fiber $Z$-line rupture (38). Such muscle work also causes large delayed increases in serum creatine kinase (39), and these increases likewise can be seen in relation to occupational work $(40,41)$. Such changes are common findings in muscle soreness, and they are reversible if the muscle is allowed to rest and recover. Repair of muscle injury includes the regeneration of contractile fibers, as well as that of connective tissue (42). Often repair is greater than the original damage, and in such cases the muscle adapts to tolerate the stress that caused the damage. Repair of a single case of damage should be complete after a few weeks or months. However, if damage occurs daily due to a work activity, the capacity of the muscle may be insufficient to repair the damage as fast as it occurs, and long-lasting impairment can develop.

When a muscle is fatigued repeatedly without sufficient recovery being allowed for, muscle disorders are likely to occur, as has already been discussed. The precise mechanism on a subcellular level is not yet known and may not be due only to the mechanical events in the muscle, but, in occupational disorders, it more often may be related to metabolic events in the muscle. Depletion of energy can result in activity-related pain (43).

Lately, attention has been drawn to the accumulation of calcium $(\mathrm{Ca})$ ions in the intracellular space (44). Calcium is released from the sarcoplasmic reticulum during contraction and can enter the muscle cell. Insufficient clearance of $\mathrm{Ca}^{++}$from the cytosolic space causes the $\mathrm{Ca}^{++}$concentration to increase, and the increment has serious implications in that $\mathrm{Ca}^{++}$ increases phospholipase activity, which can break down the membrane lipids and cause increased cell membrane permeability and an accumulation of toxic metabolites. In addition $\mathrm{Ca}^{++}$increases the susceptibility of the membrane lipids to free radicals, which are formed during reoxygenation of hypoxic tissue. Finally, $\mathrm{Ca}^{++}$overload can alter mitochondrial function (45).

Larsson et al (46) and Lindman et al (47) reported differences in muscle morphology that suggest that subjects with chronic myofascial pain have a lower capacity and higher levels of fatigue than normal subjects. These mechanisms are consistent with the pathologically high rates of fatigue and low strength reported by Hagberg \& Kvarnström (48) for patients with myofascial shoulder pain. Reduced local blood flow in the trapezius muscle was correlated with myalgia and ragged red fibers in 17 patients with chronic myalgia and was related to static load during repetitive assembly work (49). In particular the active muscle fibers can be insufficiently perfused due to increased pressure in these areas (50). Disturbance in muscular microcirculation can lead to the sensitization of pain receptors (nociceptors) in the muscle and pain at rest. Pain receptor sensitization means that low threshold stimuli can activate the pain system or that even spontaneous activity can occur in nociceptive nerves (51).

Motor control of the working muscle plays a crucial role in the development of disorders. The recruitment pattern of the motoneurons can occur according to the size principle (ie, the small units are activated at low forces) $(52,53)$. Consequently, the same unit can be recruited continuously during a given work task. Therefore, even if the relative load on the muscle as a whole is low, the active motor unit can work close to its maximal capacity. These lowthreshold motor units may have a high risk of being damaged (54). Actually, these units have been identified as showing marked morphological changes, described as red ragged fibers (55). Another mechanism to induce a stereotype recruitment pattern is the activation of gamma motoneurons due to ischemia or the accumulation of metabolites (56). Finally, the generation of muscle tension due to mental load can cause an overload on some specific muscle fibers (57). In addition, Edwards (58) has published "Hypothesis of Peripheral and Central Mechanisms Underlying Occupational Muscle Pain and Injury."

From this discussion it can be seen how an exertion of the body leads to a series of responses. The magnitude of each response depends on the capacity of the tissue and its exposure to previous responses. Some of these steps are summarized in table 2 . The ultimate reporting of fatigue and pain depends on their effect on work capacity relative to work demands and on socioeconomic factors.

\section{Tendon disorders}

Tendon dose is related to tensile forces from muscle contractions and to contact and shearing forces from adjacent anatomic surfaces (eg, bones and ligaments). Tendon responses can be mechanical or physiological. Mechanical responses include elastic and viscous deformation and yielding. Physiological responses include the triggering of nerve receptors, healing, and adaptation.

The most common sites of tendon disorders among industrial workers are the wrist, forearm, elbow, and shoulder $(6,40,59,60)$. The terminology for tendon disorders is not well defined. Kurppa et al (61) used tenosynovitis for inflammation of the tendon sheath and peritendinitis for inflammation of the paratendon.

The pathogenesis of shoulder tendinitis is fairly well understood. The predisposing factor for shoulder tendinitis is often degeneration. Degeneration of the tendon is caused by impairment of perfusion and nutrition, in addition to mechanical stress. Cell death within the tendon, forming debris in which chalk can deposit, is the initial form of degeneration. The tendons to the supraspinata, the biceps brachii (long head), and the upper parts of the infraspinata mus- 
cle have zones of avascularity $(62,63)$. Signs of degeneration such as cell death, chalk deposits, and microruptures are located predominantly in this area of avascularity. Impairment of the circulation and thus accelerated degeneration is caused by compression and static tension of the shoulder tendons. The compression of the tendons occurs when the arm is elevated. During elevation of the arm, the rotator cuff tendons and the insertions on the greater tuberosity are compressed under the coracoacromial arch. It is believed that this compression or impingement is sufficient to impair perfusion of the tendon.

Tendon circulation is also dependent on muscle tension. Circulation in the tendon is inversely proportional to the tension and ceases at greater tensions. Recent studies have shown that the intramuscular pressure in the supraspinata muscle exceeds $30 \mathrm{~mm}$ $\mathrm{Hg}(\approx 3.99 \mathrm{kPa})$ at 30 degrees of forward flexion or abduction in the shoulder joint $(3,64)$. An impairment of blood circulation occurs at this pressure level. Since the major blood vessel supplying the supraspinata tendon runs through the supraspinata muscle, it is likely that the circulation of the tendon may be disturbed already at 30 degrees of forward flexion or abduction in the shoulder joint.

These deformations can increase with successive exertions due to the viscoelastic properties of tendons. Goldstein et al (65) demonstrated that, when flexor digitorum profundus tendons were subjected to 500 repetitions of an 8-s axial load followed by $2 \mathrm{~s}$ of rest, the viscous strain was equal to the elastic strain. When a 2 -s load was followed by $8 \mathrm{~s}$ of rest, the viscous strain was negligible. Repeated or prolonged exertions with insufficient recovery time can lead to a deformation of tendons and reduced perfusion that persists well beyond the period of work.

In the degenerated tendon, it is possible that exertion triggers an inflammatory "foreign body" response to the debris of dead cells and results in active tendinitis. In addition, infection (viral, urogenital) or systemic inflammation may predispose a subject to reactive tendinitis in the shoulder. One hypothesis is that an infection that makes the immune system active increases the possibility of a "foreign body" response to the degenerative structures in the tendon.

The pathogenesis of lateral epicondylitis is not yet well understood. The predominant theory is that microruptures occur at the attachment of the muscle to the bone, more specifically between the insertion and the periosteum of the bone, causing inflammation $(66-68)$. This phenomenon could be due to repetitive high force exceeding the strength of the collagen fibers of the tendon origin. The microtear, usually in the origin of the extensor carpi radialis brevis, results in the formation of fibrons and granular tissues as a consequence of repetitive trauma (69).

Tendons are kept in place at the wrist by ligamentous compartments. The first dorsal wrist compartment can be narrow and cause excessive friction dur- ing movements of the wrist, and this friction leads to inflammation and swelling of the tendons. Tendinitis has been induced in the Achilles tendon of rabbits by electrical stimulus leading to repetitive contractions (70).

Extensive work can also be performed in sports, and thus there is a strong analogy between work-related and sport-related tendinitis. Competitive swimmers with repetitive overhead arm movements are at risk for impingement syndrome (71). Lateral epicondylitis is known as tennis elbow since the condition has been attributed to tennis playing. (See, eg, reference 72.)

As in muscle responses, it can be seen how an exertion of the body leads to a series of tendon responses, which are summarized in table 2 .

Table 2. Characterization of work-related musculoskeletal disorders in general and muscle, tendon, and nerve disorders in particular according to sets of cascading exposure and response variables as conceptualized in the model.

\begin{tabular}{|c|c|c|}
\hline Exposure-dose & Individual's capacity & Response \\
\hline \multicolumn{3}{|c|}{ Musculoskeletal system } \\
\hline $\begin{array}{l}\text { Work load } \\
\text { Work location } \\
\text { Work frequency } \\
\text { Work duration }\end{array}$ & $\begin{array}{l}\text { Body size and shape } \\
\text { Physiological state } \\
\text { Psychological state }\end{array}$ & $\begin{array}{l}\text { Joint position } \\
\text { Muscle force } \\
\text { Muscle length } \\
\text { Muscle velocity } \\
\text { Frequency }\end{array}$ \\
\hline \multicolumn{3}{|c|}{ Muscle disorders } \\
\hline $\begin{array}{l}\text { Muscle force } \\
\text { Muscle velocity } \\
\text { Frequency } \\
\text { Duration }\end{array}$ & $\begin{array}{l}\text { Muscle mass } \\
\text { Muscle anatomy } \\
\text { Fiber type } \\
\text { composition } \\
\text { Enzyme concen- } \\
\text { tration } \\
\text { Energy stores } \\
\text { Capillary density }\end{array}$ & $\begin{array}{l}\text { Membrane permeability } \\
\text { lon flow } \\
\text { Membrane action } \\
\text { potentials } \\
\text { Energy turnover } \\
\text { (metabolism) muscle } \\
\text { enzymes, and energy } \\
\text { stores } \\
\text { Intramuscular pressure } \\
\text { lon imbalances } \\
\text { Reduced substrates } \\
\text { Increased metabolites } \\
\text { and water } \\
\text { Increase in blood } \\
\text { pressure, heart rate, } \\
\text { cardiac output, } \\
\text { muscle blood flow } \\
\text { Muscle fatigue } \\
\text { Pain } \\
\text { Free radicals } \\
\text { Membrane damage } \\
\text { Z-disc ruptures } \\
\text { Afferent activation }\end{array}$ \\
\hline \multicolumn{3}{|c|}{ Tendon disorders } \\
\hline $\begin{array}{l}\text { Muscle force } \\
\text { Muscle length } \\
\text { Muscle velocity } \\
\text { Frequency } \\
\text { Joint position } \\
\text { Compartment } \\
\text { pressure }\end{array}$ & $\begin{array}{l}\text { Anthropometry } \\
\text { Tendon anatomy } \\
\text { Vascularity } \\
\text { Synovial tissue }\end{array}$ & $\begin{array}{l}\text { Stress } \\
\text { Strain (elastic \& viscous) } \\
\text { Microruptures } \\
\text { Necrosis } \\
\text { Inflammation } \\
\text { Fibrosis } \\
\text { Adhesions } \\
\text { Swelling } \\
\text { Pain }\end{array}$ \\
\hline \multicolumn{3}{|l|}{ Nerve disorders } \\
\hline $\begin{array}{l}\text { Muscle force } \\
\text { Muscle length } \\
\text { Muscle velocity } \\
\text { Frequency } \\
\text { Joint position } \\
\text { Compartment } \\
\text { pressure }\end{array}$ & $\begin{array}{l}\text { Anthropometry } \\
\text { Nerve anatomy } \\
\text { Electrolyte status } \\
\text { Basal compartment } \\
\text { pressure }\end{array}$ & $\begin{array}{l}\text { Stress } \\
\text { Strain } \\
\text { Ruptures in perineural } \\
\text { tissues } \\
\text { Protein leakage } \\
\text { Ruptures in perineural } \\
\text { tissue } \\
\text { Protein leakage in nerve } \\
\text { trunks } \\
\text { Edema } \\
\text { Increased pressure } \\
\text { Impaired blood flow } \\
\text { Numbness, tingling, } \\
\text { conduction block } \\
\text { Nerve action } \\
\text { potentials }\end{array}$ \\
\hline
\end{tabular}




\section{Nerve disorders}

As with tendons, the concept of dose, when applied to nerves, implies muscle contractions, joint positions, and joint movements which produce pressure and deformation of the nerves. Some individuals experience responses that continue well beyond the normal contraction. In addition, nerve pressure and deformation can persist after the contraction as a secondary effect of the swelling of adjacent tendons and tendon sheaths. Mechanical responses in turn lead to a series of physiological responses that ultimately include impaired nerve function. Nerves can also be affected by exposure to vibration and low temperatures.

Lundborg et al (73) showed that intracarpal canal pressure can lead to impaired conduction and sensory function of the median nerve in less than $1 \mathrm{~h}$. An increase in carpal tunnel pressure of three to six times the resting value was found during isometric or isotonic maximal contractions of wrist and finger muscles (74). These changes were related to mechanical pressure and perfusion of the median nerve.

A response is an effect of the dose caused by exposure. Impaired circulation in the median nerve results in tingling, numbness, pain, and a loss of motor function in the hand. The impaired function in the nerve can be measured by nerve conduction velocity changes or sensory threshold shifts (73). It has also been claimed that pain in the shoulder can be proximal entrapment pain triggered by compression of the median nerve at the wrist (75).

Compression of the median nerve in certain postures is the basis of "Phalen's" or the "wrist flexion" test for carpal tunnel syndrome and other provocative tests of nerve function (23). The acute response to exposure modified by capacity has been described, but the model can also be applied to chronic (longstanding) effects. Wrist extension (the exposure) may cause "stretching of the nerve" (the dose) leading to microruptures (the response). In turn, these microruptures may be considered a dose generating the response of inflammation. Inflammation is then considered a dose with a response of tissue scarring. Tissue scarring alters the capacity of the nerve and may also be a dose of pressure increase. A permanent pressure increase may lead to nerve degeneration due to impaired blood perfusion. A pressure increase has already been shown to block the outward and inward axoplasmic flows in the nerve $(75,76)$.

Microscopic studies of tissues in the carpal tunnel in wrist specimens have revealed changes (eg, increased thickening of fibrocytes and fibrous connective tissue) in the radial and ulnar bursa and the median nerve (77). The pattern of these changes corresponds with the pattern of stresses produced between the tendons, nerves, and adjacent flexor retinaculum and carpal bones. It was suggested that repeated exertions with a flexed or extended wrist are important factors in the etiology. The authors con- cluded that these stresses and tissue changes were involved in the pathogenesis of activity, related carpal tunnel syndrome. Similar observations and conclusions have been made by other investigators (23).

The effect of a given dose depends on the individual's capacity. Whether an increase in carpal tunnel pressure causes an impairment of blood flow in the nerve is dependent upon blood pressure. Individuals with high blood pressure require higher intracarpal tunnel pressure elevation to decrease blood flow and impair nerve function (78). Whether large or small carpal tunnel areas increase the risk for carpal tunnel syndrome is a disputed issue $(79,80)$. It may be that the residual volume plays an important role (81). Hormonal status may influence the pressure in the carpal canal. High levels of estrogen in pregnancy (82) increase the retention of water in the body. Metabolic disorders may make the nerve more susceptible to pressure increases in the carpal tunnel. Examples of metabolic disorders are diabetes mellitus and amyloidosis. Compression of the median nerve proximal to the wrist (eg, the thoracic outlet) may make the nerve more susceptible to an impairment of blood flow in the wrist (double crush syndrome) (75).

Other investigators have shown that peripheral nerve disorders can result from the transmission of pressure from an external work object through the skin to an underlying nerve (83-86). A localized pressure above $50 \mathrm{~mm} \mathrm{Hg}(\approx 6.65 \mathrm{kPa})$ in the carpal tunnel or pressure above the systolic level from a tourniquet around the upper arm causes a conduction block in the median nerve at the wrist $(73,78)$. Extreme flexion or extension of the wrist causes an increase of pressure in the carpal tunnel that can affect the blood perfusion of the median nerve $(74,87$, 88 ).

In the case of materials handling, it is evident that the poor ergonomic design of tools with respect to weight, shape, and size can impose extreme wrist positions and the use of high forces on the worker $(89,90)$. Holding an object requires a power grip and high tension in the finger flexor tendons that cause increased pressure in the carpal tunnel. The heavier the object, the greater the power required to hold the object.

Hand and arm vibration causes an involuntary increase in power grip through a reflex of the strength receptors (91). Furthermore, vibration can cause protein leakage from the blood vessels in the nerve trunks and result in edema and increased pressure in the nerve trunks and therefore also result in edema and increased pressure in the nerve (92).

As is the case with muscles and tendons, exertion of the body results in a series of mechanical and physiological doses and responses of the nerves. Doses and responses of a certain type and magnitude are necessary for a nerve to function, but other doses and responses can impair its function. In time, nerves adapt in ways that increase their tolerance to increasing doses. There appears to be a series of 
thresholds between the dose levels necessary for normal function and those which lead to impaired function. The thresholds appear to vary among people and within people over time.

\section{Psychosocial interaction}

In the previous sections the interactions between doses and responses in different tissues such as muscle, tendon, and nerve have been indicated. The interactions between psychosocial exposures, psychological factors, and tissue responses are less well established, but possible pathways have been described by, for example, Theorell et al (93). The quantitative relationships, however, need to be described in future research.

\section{Use of the model}

The proposed model should be useful in the design of studies on the etiology and pathomechanisms of work-related musculoskeletal disorders, as well as in the planning and evaluation of preventive programs. Epidemiologic studies among working populations usually focus on associations between the top and bottom of the cascade (see figure 1) with physical work load, psychological demands, and environmental risk factors of work at one end and the manifestations of symptoms, diseases, or disabilities at the other. Unbalanced age, gender, and work histories are frequent problems for epidemiologic studies. These factors can be controlled in laboratory studies, but it is unethical to expose human subjects to a situation that is believed a priori will make them sick. The model can be used to identify intermediate responses, such as intracarpal canal pressure, to evaluate selected exposure factors with minimum risk to the human subject.

An important question concerning research is how well exposure, dose, response, and capacity can be measured and quantified. Various studies have assessed exposure using job title or job classification, questionnaires on possible risk factors, job checklists filled out by the researchers, observations, and direct measurements (94), with quantifiability and cost of assessment increasing as one moves from the beginning to the end of the list. The use of quantifiable methods has been strongly encouraged, and several methods are available. (See, eg, references 9597.) If one wants to extend the measuring time (ie, assess long-term cumulative exposure), there are few methods of direct measurement (eg, goniometers) and the cost of such studies is of major concern. Repeated use of validated checklists is less costly, and the development of a job-exposure matrix (ie, individual exposure profiles) is more economical for an assessment of cumulative exposure. However, it has been difficult to find the best compromise between the precision and cost of direct measurement exposure with the loss of precision and accuracy of the less expensive checklist or questionnaire methods.

Muscle force and joint position are probably the most commonly used methods to estimate dose. To measure capacity, anthropometry, muscle strength, and psychological characteristics have been used. Muscle biopsies can also be used, but tendon and nerve biopsies are not ethnically acceptable.

The responses range from pain, fatigue, discomfort, or other subjective symptoms to more objective factors such as nerve action potentials, muscle action potentials, ruptures, and edema, many of which can be quantified only under laboratory conditions $(98,99)$. Some of the objective responses mentioned can be measured at the workplace, but it is more usual to rely on subjective assessment, often combined with a clinical examination. Several components of clinical tests have been not adequately validated and need further evaluation.

The measurement and quantification of exposure, dose, capacity, and response is encouraged whenever possible. By applying the model, the open-minded researcher may discover new exposures, doses, capacities, and responses, which, after their discovery, can be quantified.

Modeling is becoming increasingly common in both social and natural science. The strength of modeling, given a high validity of the model, is that the outcome of a series of events can be predicted without extensive experimentation. In the case of musculoskeletal disorders, a validation of the entire model through laboratory or epidemiologic studies is hardly conceivable, due to the long-lasting disease process.

The hypotheses underlying attempts to prevent work-related musculoskeletal disorders are seldom formally stated; in many cases the prevention programs can be described as "trial and error" exercises. Most attempts are never evaluated, and therefore the validity of the original hypothesis cannot be tested. The proposed model can be used to identify intermediate doses and responses.

\section{Concluding remarks}

The proposed model addresses the complex, multifactorial nature of work-related neck and upper-limb disorders. It has been developed through the experience and results of research in many disciplines. It provides a clear framework for understanding the complex nature of the interactions between exposure, dose, capacity, and response.

It is hoped that one use of the model will be to aid researchers in identifying dose and response variables in their studies. In particular, the use of the model should generate more efficient planning and evaluation of both research addressing the etiology and pathomechanisms of these disorders and intervention and prevention studies. 


\section{References}

1. World Health Organization (WHO). Identification and control of work-related diseases. Geneva: WHO, 1985:7-11. (Technical report; no 174.)

2. Bjelle A, Hagberg M, Michaelson G. Clinical and ergonomic factors in prolonged shoulder pain among industrial workers. Scand J Work Environ Health $1979 ; 5: 205-10$.

3. Herberts P, Kadefors R, Högfors C, Sigholm G. Shoulder pain and heavy manual labor. Clin Orthop Relat Res 1984;191:166-78.

4. Roto P, Kivi P. Prevalence of epicondylitis and tenosynovitis among meatcutters. Scand J Work Environ Health 1984;10:203-5.

5. Kurppa K, Viikari-Juntura E, Kuosma E, Huuskonen $\mathrm{M}$, Kivi P. Incidence of tenosynovitis or peritendinitis and epicondylitis in a meat-processing factory. Scand J Work Environ Health 1991;17:32-7.

6. Viikari-Juntura E, Kurppa K, Kuosma E, Huuskonen M, Kuorinka I, Ketola R, Könni U. Prevalence of epicondylitis and elbow pain in the meat-processing industry. Scand J Work Environ Health 1991;17:3845.

7. Kuorinka I, Koskinen P. Occupational rheumatic diseases and upper limb strain in manual jobs in a light mechanical industry. Scand J Work Environ Health 1979;5 suppl 3:39-47.

8. Luopajärvi T, Kuorinka I, Virolainen M, Holmberg M. Prevalence of tenosynovitis and other injuries of the upper extremities in repetitive work. Scand J Work Environ Health 1979;5 suppl 3:48-55.

9. Armstrong TJ, Fine LJ, Goldstein SA, Lifshitz YR, Silverstein BA. Ergonomics considerations in hand and wrist tendinitis. J Hand Surg 1987;12A(5, part 2): $830-7$.

10. McCormack RR Jr, Inman RD, Wells A, Berntsen C, Imbus HR. Prevalence of tendinitis and related disorders of the upper extremity in a manufacturing workforce. J Rheumatol 1990;17(7):958-64.

11. Hünting W, Läubli T, Grandjean E. Postural and visual loads at VDT workplaces. Ergonomics 1981;24: $917-31$

12. Amano M, Umeda G, Nakajma H, Yatsuki K. Characteristics of work actions of shoe manufacturing assembly line workers and a cross-sectional factor-control study on occupational cervicobrachial disorders. Jpn J Ind Health 1988;30:3-12.

13. Cannon LJ, Bernacki EJ, Walter SD. Personal and occupational factors associated with carpal tunnel syndrome. J Occup Med 1981;23(4):255-8.

14. Falck B, Aarnio P. Left-sided carpal tunnel syndrome in butchers. Scand J Work Environ Health 1983;9: $291-7$.

15. Silverstein BA, Fine LJ, Stetson D. Hand-wrist disorders among investment casting plant workers. J Hand Surg 1987; 12A(5, part 2):838-44.

16. Nathan PA, Meadows KD, Doyle LS. Relationship of age and sex to sensory conduction of the median nerve at the carpal tunnel and association of slowed conduction with symptoms. Muscle Nerve 1988;11:1149-53.

17. Chiang H, Chen S, Yu H, Ko Y. The occurrence of carpal tunnel syndrome in frozen food factory employees. Kaohsiung J Med Sci 1990;6:73-80.

18. Wieslander G, Norbäck D, Göthe C, Juhlin L. Carpal tunnel syndrome (CTS) and exposure to vibration, repetitive wrist movements, and heavy manual work: a case-referent study. Br J Ind Med 1989;46:43-7.

19. Franklin GM, Haug J, Heyer N, Checkoway H. Occupational carpal tunnel syndrome in Washington State, 1984-1988. Am J Public Health 1991;81: $741-6$.

20. Little JM, Ferguson DA. The incidence of the hypothenar hammer syndrome. Arch Surg 1972;105:684 5 .
21. Nilsson T, Burström L, Hagberg M. Risk assessment of vibration exposure and white fingers among platers. Int Arch Occup Environ Health 1989;61:473-81.

22. Margolis W, Kraus JF. The prevalence of carpal tunnel syndrome symptoms in female supermarket checkers. J Occup Med 1987;12:953--6.

23. Phalen GS. The carpal-tunnel syndrome: seventeen years' experience in diagnosis and treatment of six hundred fifty-four hands. J Bone Jt Surg 1966;48A(2): $211-28$.

24. Stevens JC, Sun S, Beard CM, O'Fallon WM, Kurland LT. Carpal tunnel syndrome in Rochester, Minnesota, 1961 to 1980 . Neurology $1988 ; 38: 134-8$.

25. Wisseman CL, Badger D (Eastman Kodak Company), US Department of Health, Education, and Welfare. Hazard evaluation and technical assistance report no TA 76 - 93. Cincinnati, OH: US Department of Health, Education, and Welfare, 1977.

26. Dimberg L, Olafsson A, Stefansson E, Aagaard H, Oden A, Andersson GBJ, Hagert C, Hansson T. Sickness absenteeism in an engineering industry: an analysis with special reference to absence for neck and upper extremity symptoms. Scand J Soc Med 1989; 17:77-84.

27. Hullman B. Phychosocial risk factors for musculoskeletal disorders in occupations of the service sectors. In: Osterholz U, et al, ed. Work-related musculo-skeletal disorders: proceedings of an international symposium. Bonn: Forschungsberichtsreihe Humanisierund des Arbeitslebens, 1987:318-28.

28. Silverstein BA, Fine LJ, Armstrong TJ. Occupational factors and carpal tunnel syndrome. Am J Ind Med 1987; 11:343-58.

29. Wilkes B, Stammerjohn L, Lalich N. Job demands and worker health in machine-paced poultry inspection. Scand J Work Environ Health 1981;7 supp 1 4:12-9.

30. Vihma T. Sewing-machine operators' work and musculo-skeletal complains. Ergonomics 1982;25(4): 295-8.

31. Kvarnström S. Occurrence of musculoskeletal disorders in a manufacturing industry, with special attention to occupational shoulder disorders. Scand J Rehabil Med 1983;8:1-114.

32. Punnett L, Robins JM, Wegman DH, Keyserling WM. Soft tissue disorders in the upper limbs of female garment workers. Scand J Work Environ Health 1985;11: 417-25.

33. Leino P. Symptoms of stress production and musculoskeletal disorders. J Epidemiol Community Health 1989;43:293-300.

34. Järvholm U, Styf J, Suurkula M, Herberts P. Intramuscular pressure and muscle blood flow in supraspinatus. Eur J Appl Physiol Occup Physiol 1988;58:219— 24.

35. Jensen B. Isometric contractions of small muscle groups [dissertation]. Copenhagen: National Institute of Occupational Health and University of Copenhagen, 1991.

36. Vøllestad N, Sejersted O. Biochemical correlates of fatigue. Eur J Apppl Physiol Occup Physiol 1988;57: $336-47$.

37. Sjøgaard G. Exercise-induced muscle fatigue: the significance of potassium. Acta Physiol Scand 1990;140 suppl 593:1-64.

38. Fridén J, Sjöström M, Ekblom B. A morphological study on delayed muscle soreness. Experientia 1981;37:506-7.

39. Newham D, Jones D, Edwards R. Plasma creatine kinase changes after eccentric and concentric contractions. Muscle Nerve 1986;9:59-63.

40. Hagberg M, Michaelson G, Ortelius A. Serum creatine kinase as an indicator of local muscular strain in experimental and occupational work. Int Arch Occup Environ Health 1982;50:377-86. 
41. Mairiuax P, Bettonville MN, Mawet M, Malchaire J. Serum creatine kinase relationship to postural constraint in manual work. Int Arch Occup Environ Health 1986;58:61-9.

42. Wahl S, Renstrom P. Fibrosis in soft-tissue injuries. In: Leadbetter WB, Buckwalter JA, Gordon SL, ed. Sports induced inflammation: clinical and basic science concepts. Park Ridge, IL: American Academy of Orthopaedic Surgeons, 1990: 644.

43. Layzer RB, Rowland LP. Muscular pain. N Engl J Med $1971 ; 285: 31$

44. Jackson MJ, Jones DA, Edwards RHT. Vitamin E and muscle diseases. J Int Metabol Dis 1985:1 suppl 8; $84-7$.

45. Lovlin R, Cottle W, Pyke I, Kavanagh M, Belcastro A. Are indices of free radical damage related to exercise intensity. Eur J Appl Physiol Occup Physiol 1987;56:313-6.

46. Larsson SE, Bengtsson A, Bodegard L, Henriksson $\mathrm{KG}$, Larsson J. Muscle changes in work-related chronic myalgia. Acta Orthop Scand 1988;59(5):552 - 6 .

47. Lindman R, Hagberg M, Ängqvist K-A, Söderlund K, Hultman E, Thornell L-E. Changes in muscle morphology in chronic trapezius myalgia. Scand J Work Environ Health 1991;17:347-55.

48. Hagberg M, Kvarnström S. Muscular endurance and electromyographic fatigue in myofascial shoulder pain. Arch Phys Med Rehabil 1984;65:522-5.

49. Larsson SE, Bodegard I, Henriksson KG, Öberg PA. Chronic trapezius myalgia: morphology and blood flow studied in 17 patients. Acta Orthop Scand 1990; 61(5):394-8.

50. Sjøgaard G, Kiens B, Jørgensen K, Saltin B. Intramuscular pressure, EMG and blood flow during low-level prolonged static contraction in man. Acta Physiol Scand 1986;128:475-84.

51. Henriksson KG, Bengtsson A. Fibromyalgia - a clinical entity? Can J Physiol Pharmacol 1991;69:6727.

52. Binder M, Bawa P, Ruenzel P, Henneman E. Does orderly recruitment of motor neurons depend on the existence of different types of motor units. Neurosci Lett 1983;6:55-8.

53. Henneman E. Relation between size of neurons and their susceptibility to discharge. Science $1957 ; 126$ : 1345 - 6.

54. Hägg G. Static work loads and occupational myalgia - a new explanation model. In: Anderson P, Hobart D, Danoff J, ed. Electromyographical kinesiology. New York, NY: Elsevier Science Publishers BV, 1991:141-4.

55. Henriksson K. Muscle pain in neuromuscular disorders and primary fibromyalgia. Eur J Appl Physiol Occup Physiol 1988;57:348-52.

56. Johansson H, Sojka P. Pathophysiological mechanism involved in genesis and spread of muscular tension in occupational muscle pain and in chronic musculoskeletal pain syndromes - a hypothesis. Med Hypotheses 1991;35:196-203.

57. Westgaard RH, Bjørklund R. Generation of muscle tension additional to postural muscle load. Ergonomics 1987;30(6):911-23.

58. Edwards RHT. Hypothesis of peripheral and central mechanisms underlying occupational muscle pain and injury. Eur J Appl Physiol 1988;57:275-81.

59. Dimberg L. The prevalence and causation of tennis elbow (lateral epicondylitis) in a population of workers in an engineering industry. Ergonomics 1987;30(3): $573-80$

60. Viikari-Juntura E. Tenosynovitis, peritendinitis and the tennis elbow syndrome. Scand J Work Environ Health 1984;10:443-9.

61. Kurppa K, Waris P, Rokkanen P. Peritendinitis and tenosynovitis: a review. Scand J Work Environ Health
1979;5 supp1 3:19-24.

62. Macnab I. Rotator cuff tendinitis. Ann R Col Surg Engl 1973;53:271-87.

63. Rathburn JB, Macnab I. The microvascular pattern of the rotator cuff. J Bone Jt Surg 1970;52B:540-53.

64. Herberts P, Kadefors R, Andersson G, Petersen I. Shoulder pain in industry: an epidemiological study on welders. Acta Orthop Scand 1981;52:299-306.

65. Goldstein SA, Armstrong TJ, Chaffin DB, Matthews LS. Analysis of cumulative strain in tendons and tendon sheaths. J Biomech 1987;20(1):1-6.

66. Coonrad RW, Hooper WR. Tennis elbow: its course, natural history, conservative and surgical management. J Bone Jt Surg 1973;55A(6):1177-82.

67. Cyriax JH. The pathology and treatment of tennis elbow. J Bone Jt Surg 1936;18:921-40.

68. Goldie I. Epicondylitis lateralis humeri (epicondylalgia or tennis elbow): a pathogenetical study. Acta Chir Scand Suppl 1961;339:1-119.

69. Leach RE, Miller JK. Lateral and medial epicondylitis of the elbow. Clin Sports Med 1987;6(2):259-72.

70. Rais O. Peritenomyositis (peritendinitis) crepitans acuta. Acta Chir Scand Suppl 1961:268:1-100.

71. Kennedy JC, Hawkins R, Krossoff WB. Orthopaedic manifestations of swimming. Am J Sports Med 1978; 6:309-22.

72. Priest JD, Jones HH, Tichenor CJ, Nagel DA. Arm and elbow changes in expert tennis players. Minn Med 1977;60(5):399-404.

73. Lundborg G, Gelberman RH, Minteer-Convery M, Lee YF, Hargens AR. Median nerve compression in the carpal tunnel - functional response to experimentally induced controlled pressure. J Hand Surg 1982;7(3): 252-9.

74. Werner CO, Elmquist D, Ohlin T. Pressure and nerve lesions in the carpal tunnel. Acta Orthop Scand 1983;54:312-6.

75. Hurst LC, Weissberg D, Carroll RE. The relationship of the double crush to carpal tunnel syndrome (an analysis of 1,000 cases of carpal tunnel syndrome). $\mathbf{J}$ Hand Surg 1985;10B(2):202-4.

76. Lundborg G. Nerve injury and repair. Edinburgh: Churchill Livingstone, 1988:76.

77. Armstrong TJ, Castelli WA, Evans G, Diaz-Perez R. Some histological changes in carpal tunnel contents and their biomechanical implications. J Occup Med 1984;26(3): 197-201.

78. Szabo RM, Gelberman RH. The pathophysiology of nerve entrapment syndromes. J Hand Surg 1987; $12 \mathrm{~A}(5): 880-4$.

79. Bleecker ML, Bohlman M, Moreland R, Tipton A. Carpal tunnel syndrome: role of carpal canal size. Neurology 1985;35(11):1599-1604.

80. Winn FJ, Habes DJ. Carpal tunnel area as a risk factor for carpal tunnel syndrome. Muscle Nerve 1990;13: 254-8.

81. John V, Nau HE, Nahser HC, Reinhat V, Venjakob K. CT of carpal tunnel syndrome. Am J Neuroradiol 1983;4: $770-2$.

82. Voitk AJ, Mueller JC, Farlinger DE, Johnston RU. Carpal tunnel syndrome in pregnancy. Can Med Assoc J 1983;128:277-81.

83. Dobyns JH, O'Brien ET, Linscheid RL, Farrow GM. Bowler's thumb: diagnosis and treatment. J Bone $\mathrm{Jt}$ Surg 1972;54-A(4):751-5.

84. Hoffman J, Hoffman PL. Staple gun carpal tunnel syndrome. J Occup Med 1985;27(11):848-9.

85. Kendall D. Aetiology, diagnosis, and treatment of paraesthesiae in the hands. Br Med J 1960;3:1633 40.

86. Kisner WH. Thumb neuroma: a hazard of ten pin bowling. Br J Plast Surg 1976;29:225-6.

87. Gelberman RH, Hergenroeder PT, Hargens AR, Lundborg GN, Akeson WH. The carpal tunnel syndrome: a study of carpal tunnel pressures. J Bone Jt Surg 
$1981 ; 63 \mathrm{~A}(3): 380-3$.

88. Armstrong TJ, Chaffin DB. Some biomechanical aspects of the carpal tunnel. J Biomech 1979;12:567-70.

89. Armstrong TJ, Chaffin DB. Carpal tunnel syndrome and selected personal attributes. J Occup Med 1979; 21(7):481-6.

90. Tischauer ER. The biomechanical basis of ergonomics. New York, NY: John Wiley and Sons, 1978.

91. Hagbarth KE, Kunesch EJ, Nordin M, Schmidt R, Wallin EU. Gamma loop contributing to maximal voluntary contractions in man. J Physiol 1986;380:57591.

92. Lundborg G, Dahlin LG, Danielsen N, Hansson HA, Necking LE, Pyykkö I. Intraneural edema following exposure to vibration. Scand J Work Environ Health $1987 ; 13: 326-9$.

93. Theorell T, Harms-Ringdahl K, Ahlberg-Hult'n G, Westin B. Psychosocial job factors and symptoms from the locomotor system: a multicausal analysis. Scand J Rehabil Med 1991;23:165—73.

94. Burdorf A. Exposure assessment of risk factors for disorders of the back in occupational epidemiology. Scand J Work Environ Health 1992;18:1-9.
95. Jonsson B, Persson J, Kilbom $\AA$. Disorders of the cervicobrachial region among female workers in the electronics industry: a two-year follow up. Int $\mathrm{J}$ Ind Ergon 1988;3:1-12.

96. Kilbom $\AA$, Persson J. Disorders of the cervicobrachial region among female workers in the electronics industry. Int J Ind Ergon 1986;1(1):37-47.

97. Kilbom Å, Persson J. Work technique and its consequences for musculoskeletal disorders. Ergonomics 1987:30(2):273-9.

98. Kuorinka I, Jonsson B, Kilbom Å, Vinterberg, Biering-Sorensen, Andersson GJ. Standardized Nordic health questionnaires for the analysis of musculoskeletal symptoms. Appl Ergon 1987;18(3):233-7.

99. Kuorinka I, Viikari-Juntura E. Prevalence of neck and upper limb disorders (nld) and work load in different occupational groups: problems in classification and diagnosis. J Hum Ergol 1982;11:65-72.

Received for publication: 31 August 1992 